\title{
Microstructure, Thermal and Mechanical Properties of
} Non-Isothermally Annealed Al-Sc-Zr and Al-Mn-Sc-Zr Alloys Prepared by Powder Metallurgy

\author{
M. Vlach ${ }^{a * *}$, I. Stulíková ${ }^{a}$, B. Smola ${ }^{a}$, H. Císařová ${ }^{a}$, J. PieŠOváa ${ }^{a}$, S. Daniš ${ }^{a}$, \\ R. GEMma ${ }^{b}$, D. TANPRAYOON ${ }^{c}$ AND V. NEUBERT ${ }^{c}$
}

${ }^{a}$ Faculty of Mathematics and Physics, Charles University in Prague, Ke Karlovu 3, 12116 Prague, Czech Republic

${ }^{b}$ Institute of Material Physics, University of Göttingen, Friedrich-Hund-Platz 1, D-37077 Göttingen, Germany

${ }^{c}$ Institut für Materialprüfung und Werkstofftechnik, Freiberger Str. 1, D-38678 Clausthal-Zellerfeld, Germany

This paper reports results of a study aimed at understanding the precipitation processes occurring during the annealing of two Al-Sc-Zr-based alloys with and without Mn prepared by powder metallurgy with subsequent hot extrusion at $350^{\circ} \mathrm{C}$. Samples were isochronally annealed up to $\approx 570{ }^{\circ} \mathrm{C}$. Precipitation behaviour was studied by electrical resistometry and differential scanning calorimetry. Mechanical properties were monitored by microhardness HV1 measurements. Transmission electron microscopy examinations and X-ray diffraction of specimens quenched from temperatures of significant resistivity changes helped to identify the microstructural processes responsible for these changes. Fine (sub)grain structure develops and fine coherent $\mathrm{Al}_{3} \mathrm{Sc}$ and $/$ or $\mathrm{Al}_{3}(\mathrm{Sc}, \mathrm{Zr}$ ) particles precipitate during extrusion in both alloys. The distinct changes in resistivity (at temperatures above $\approx 330^{\circ} \mathrm{C}$ ) of the $\mathrm{Al}-\mathrm{Mn}-\mathrm{Sc}-\mathrm{Zr}$ alloy are mainly caused by precipitation of Mn-containing particles. The easier diffusion of $\mathrm{Mn}$ atoms along the (sub)grain boundaries is responsible for the precipitation of the $\mathrm{Al}_{6} \mathrm{Mn}$ and/or $\mathrm{Al}_{6}(\mathrm{Mn}, \mathrm{Fe})$ particles at relatively lower temperatures compared to the temperature range of precipitation of these particles in the classical mould-cast $\mathrm{Al}-\mathrm{Mn}-\mathrm{Sc}-\mathrm{Zr}$ alloys The apparent activation energy for precipitation of the $\mathrm{Al}_{3} \mathrm{Sc}$ and $\mathrm{Al}_{6} \mathrm{Mn}$ particles in the $\mathrm{Al}-\mathrm{Mn}-\mathrm{Sc}-\mathrm{Zr}$ alloy was determined as $(106 \pm 10) \mathrm{kJ}^{\mathrm{mol}}{ }^{-1} \mathrm{and}$ $(152 \pm 33) \mathrm{kJ} \mathrm{mol}^{-1}$, respectively.

PACS: $81.20 . \mathrm{Ev}, 81.30 . \mathrm{Mh}$

\section{Introduction}

Properties and microstructure of $\mathrm{Al}$ and its alloys are significantly influenced by a small addition of scandium $(\approx 0.2 \mathrm{wt} \%)$ and zirconium $(\approx 0.1 \mathrm{wt} \%)$ [1-8]. Positive effects on microhardness, recrystallization temperature, corrosion resistance and weldability attained due to the coherent spherical nanosized $\mathrm{Al}_{3}(\mathrm{Sc}, \mathrm{Zr})$ particles with the cubic $L 1_{2}$ structure are very pronounced [1-5, 8]. The decomposition sequence of the supersaturated solid solution of the Al-Sc-Zr-based system is known in the following form $[5,9,10]$ : Sc-rich clusters $\rightarrow \mathrm{Al}_{3} \mathrm{Sc}$ phase $\rightarrow$ layer rich in $\mathrm{Zr} \rightarrow \mathrm{Al}_{3}(\mathrm{Sc}, \mathrm{Zr})$ phase.

Impact of Mn-containing particles introduced during a heat treatment on recrystallization in the commercial Al-Mn-based alloys has been studied extensively [11-13]. The precipitation of Mn-containing particles in $\mathrm{Al}$ influences the resistivity significantly [8]. However, it has a poor effect on microhardness $[1,14,15]$. It was also recently observed that the fine-grained structure of the Al-based alloys helps to accelerate the precipitation of Mn-containing particles and the recrystallization process $[12,14,16]$.

Only few articles dealing with properties of dilute Al-Mn-based and/or Al-Sc-based alloys prepared by powder metallurgical (PM) procedure were published,

* corresponding author; e-mail: martin.vlach@mff.cuni.cz e.g. Al-Sc alloys [17], Al-Sc-Zr alloys [3, 7, 18] or Al-Mn-based alloys with $\mathrm{Ni}$ and $\mathrm{Cr}$ [19]. Powder metallurgical production of $\mathrm{Sc}$ and $\mathrm{Zr}$ containing $\mathrm{Al}$ alloys can add other improvements connected with substantial grain refinement, e.g. increase of strength, ductility, corrosion resistance, etc. [3, 18].

In the present study a comparison of two Al-Sc-Zr-based alloys prepared by powder metallurgy with and without Mn-content was done. The results of electrical resistivity measurements, microhardness, differential scanning calorimetry measurements and microstructure development were combined.

\section{Experimental procedure}

Two AlScZrPM and AlMnScZrPM alloys were studied. The alloys were prepared by mould casting. Powder from the alloys was produced by atomising in argon with $1 \%$ of oxygen and sieved to a maximum powder size of $\approx 30 \mu \mathrm{m}$. The powder was then consolidated by extrusion with reduction $70: 18$ at $350^{\circ} \mathrm{C}$. The compositions of the alloys are listed in Table I.

The alloys were isochronally annealed in steps of $30^{\circ} \mathrm{C} / 30$ min (the AlScZrPM alloy and the AlMnScZrPM alloy up to $540{ }^{\circ} \mathrm{C}$ and up to $570^{\circ} \mathrm{C}$, respectively). The isochronal annealing was performed in a stirred silicone oil bath up to $240^{\circ} \mathrm{C}$ followed by quenching into liquid nitrogen. At higher temperatures, it was performed in an air furnace (samples were wrapped in a steel foil) followed by quenching into water at room temperature (RT). 
Chemical composition of the alloys studied (wt\%).

TABLE I

\begin{tabular}{c|c|c|c|c|c|c|c|c}
\hline \hline Notation & $\mathrm{Al}$ & $\mathrm{Mn}$ & $\mathrm{Sc}$ & $\mathrm{Zr}$ & $\mathrm{Si}$ & $\mathrm{Fe}$ & $\mathrm{Ti}$ & $\mathrm{Cu}, \mathrm{Mg}, \mathrm{Zn}, \mathrm{Cr}$ \\
\hline AlScZrPM & 99.43 & 0.01 & 0.23 & 0.19 & 0.03 & 0.04 & 0.04 & $<0.03$ \\
AlMnScZrPM & 98.03 & 1.42 & 0.21 & 0.17 & 0.02 & 0.10 & - & $<0.05$
\end{tabular}

The electrical resistivity was measured at $78 \mathrm{~K}$ in liquid $\mathrm{N}_{2}$ bath by means of the DC four-point method with a dummy specimen in series within an accuracy of $\approx 10^{-4}$. The effect of a parasitic thermo-electromotive force was suppressed by changing the polarity. The deformation of electrical field in the vicinity of contacts was estimated yielding the total accuracy better than $3 \%$.

The influence of annealing on mechanical properties was studied using the Vickers microhardness (HV1) measurements at RT.

Differential scanning calorimetry (DSC) was performed at heating rates of $1,2,5,10$ and $20 \mathrm{~K} / \mathrm{min}$ in a Netzsch DSC 200 F3 apparatus. The specimen of mass between 10-15 mg was placed in $\mathrm{Al}_{2} \mathrm{O}_{3}$ crucible in a dynamic nitrogen atmosphere $(40 \mathrm{ml} / \mathrm{min})$.

X-ray diffraction (XRD) was performed in the BraggBrentano geometry on a Bruker D8 Advance diffractometer equipped with $\mathrm{Cu} \mathrm{X}$-ray tube and energetically dispersive detector for the AlMnScZrPM alloy surfaces in as-prepared state and annealed state (up to $480^{\circ} \mathrm{C}$ ).

Transmission electron microscopy (TEM) and electron diffraction (ED) were carried out in a JEOL JEM 2000FX electron microscope. Elemental analysis of the precipitated phases was carried out by energy-dispersive spectroscopy (EDX).

\section{Results and discussion}

Fine (sub)grain structure $(\approx 1 \mu \mathrm{m})$ was observed in the AlMnScZrPM alloy (see Fig. 1). TEM also proved a fine dispersion of the $\mathrm{Al}_{3} \mathrm{Sc}$ and/or $\mathrm{Al}_{3}(\mathrm{Sc}, \mathrm{Zr})$ particles with the $L 1_{2}$-structure in the as-extruded state which precipitated in grain interiors during hot extrusion at $350^{\circ} \mathrm{C}$ - see Fig. 1. Microstructure observation reveals similar microstructure in the as-prepared state in both of the AlScZrPM and AlMnScZrPM alloys. The particle size $d$ estimated from TEM images was $(6 \pm 2) \mathrm{nm}$ and $(5 \pm 2) \mathrm{nm}$ for the AlMnScZrPM and AlScZrPM alloy, respectively.

Figure 2 shows relative resistivity $\Delta \rho / \rho_{0}$ and microhardness HV1 isochronal annealing curves of the alloys. The electrical resistivity decreases from about $240^{\circ} \mathrm{C}$ to a minimum at $420^{\circ} \mathrm{C}$ for the AlScZrPM alloy and at $510^{\circ} \mathrm{C}$ for the AlMnScZrPM alloy. Higher microhardness values of the AlMnScZrPM alloy are probably due to the addition of Mn. However, the microhardness annealing response is similar for both alloys studied - the HV1 attains an indistinct maximum at $\approx 300^{\circ} \mathrm{C}$. Then microhardness of both alloys decreases.

Temperature ranges of the resistivity changes are better recognized in Fig. 3, where the negative numerical

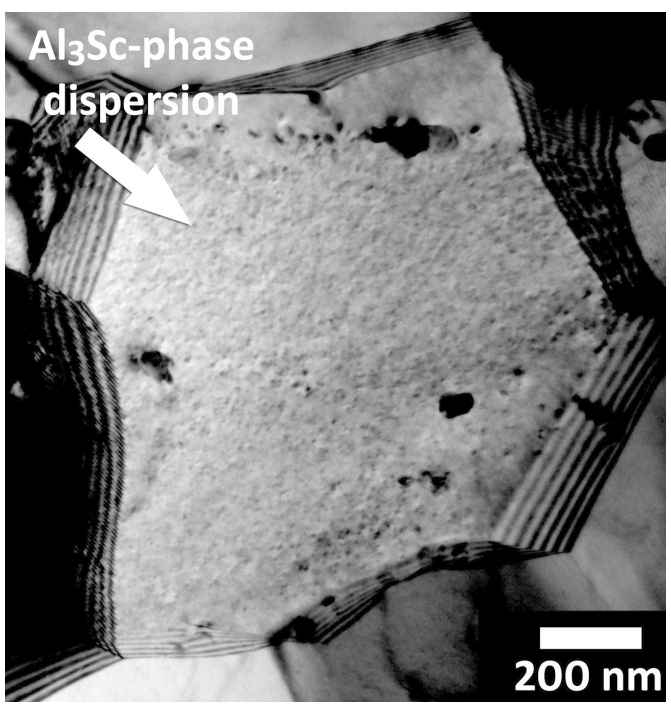

Fig. 1. TEM dark-field image of the as-prepared AlMnScZrPM alloy. Notice the fine dispersion of the $\mathrm{Al}_{3} \mathrm{Sc}$ and $/$ or $\mathrm{Al}_{3}(\mathrm{Sc}, \mathrm{Zr}$ ) particles (inside subgrain) precipitated during hot extrusion at $350{ }^{\circ} \mathrm{C}$.

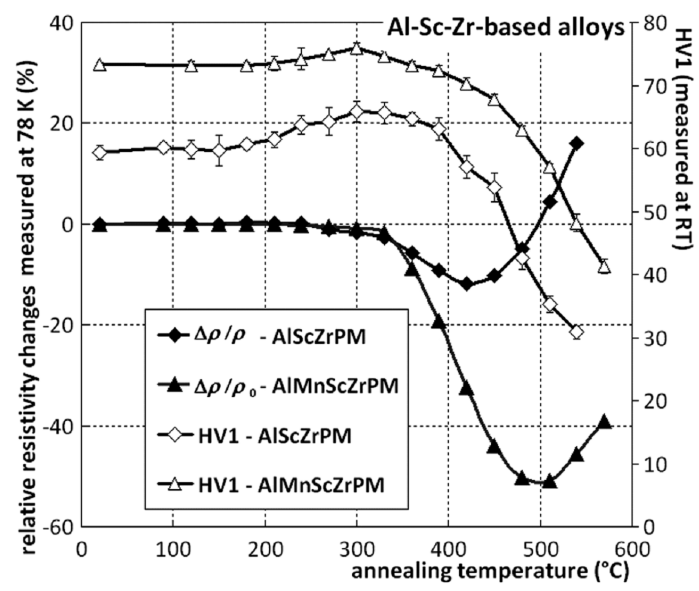

Fig. 2. Relative resistivity changes $\Delta \rho / \rho_{0}$ (measured at $78 \mathrm{~K}$ ) and microhardness HV1 (measured at RT) during the isochronal annealing in steps of $30^{\circ} \mathrm{C} / 30 \mathrm{~min}$.

derivatives (spectrum curves) of the curves from Fig. 2 are shown. The first slight resistivity decrease in the AlMnScZrPM alloy up to $\approx 300{ }^{\circ} \mathrm{C}$ (Fig. 2) as well as in the AlScZrPM alloy in the temperature range 240 $300{ }^{\circ} \mathrm{C}$ is characterized by resistivity stage (labelled as the I-stage at $\approx 270{ }^{\circ} \mathrm{C}$ in Fig. 3 ). Derivative resistivity 


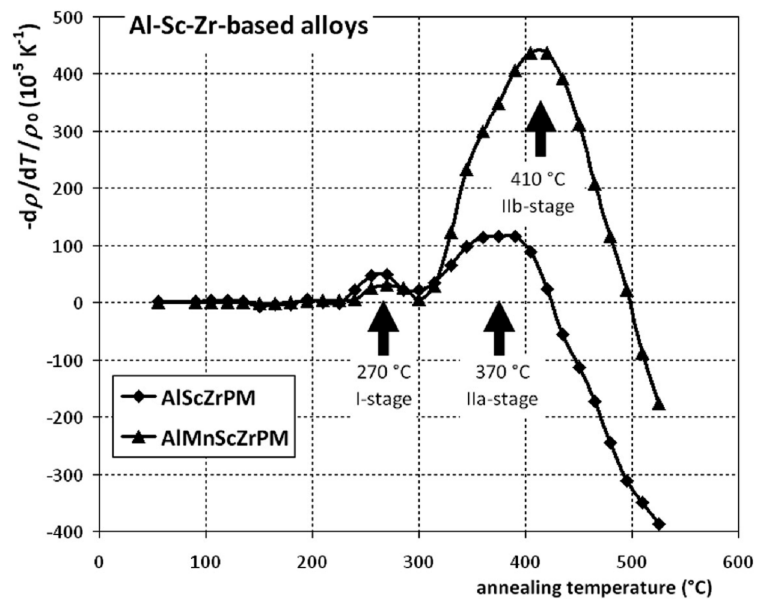

Fig. 3. Negative numerical derivatives of the measured resistivity annealing curves.

data compiled in the previous studies of the mould-cast and cold-rolled Al-Sc-Zr alloys [9] as well as the mould-cast Al-Mn-Sc-Zr-based alloys [15] do not differ in the temperature position of this stage from spectra in Fig. 3 . This stage was ascribed to the precipitation of the $\mathrm{Al}_{3} \mathrm{Sc}$ particles $[9,15]$. Thus the observed undistinguished resistivity decrease and corresponding I-stage in the annealing spectra in Fig. 3 can be ascribed to the precipitation of the $\mathrm{Al}_{3} \mathrm{Sc}$ particles, too. The precipitation of the $L 1_{2^{-}}$ -structured $\mathrm{Al}_{3} \mathrm{Sc}$ particles during the hot extrusion at $350^{\circ} \mathrm{C}$ (Fig. 1) results in lower supersaturation of Sc in the solid solution. Therefore, the decrease of electrical resistivity and the increase of microhardness of the $\mathrm{PM}$ alloys at temperatures of $\approx 300^{\circ} \mathrm{C}$ are smaller compared to the mould-cast and cold-rolled Al-Sc-Zr alloys [9] and the mould-cast Al-Mn-Sc-Zr-based alloys [9, 16]. Similar slight $\mathrm{HV}$ increase during isochronal annealing between $240-300{ }^{\circ} \mathrm{C}$ was observed in the Al-Sc-based alloys prepared by powder metallurgy where Sc-containing particles also precipitated during hot extrusion [7].

The spectra of the studied AlScZrPM and AlMnScZrPM alloys differ above $\approx 330^{\circ} \mathrm{C}$ (see Fig. 3 ). The pronounced resistivity stages are situated at $\approx 370^{\circ} \mathrm{C}$ for the AlScZrPM alloy (labelled as the IIa-stage) and at $\approx 410^{\circ} \mathrm{C}$ for the AlMnScZrPM alloy (labelled as IIb-stage).

The coarsening of the $L 1_{2}$-structured $\mathrm{Al}_{3} \mathrm{Sc}$ particles has been recently described in several publications (e.g. in Refs. $[9,10,15,20])$. First, Zr segregates at the heterophase interface of the $\mathrm{Al}_{3}$ Sc particles, afterwards the development of these particles with the $L 1_{2}$ structure leads to the formation of the $\mathrm{Al}_{3}(\mathrm{Sc}, \mathrm{Zr})$ phase. Direct TEM observation of the AlScZrPM alloy annealed up to $420^{\circ} \mathrm{C}$ proved a homogeneous distribution of the $L 1_{2^{-}}$ -structured precipitates (see Fig. 4) with Sc and Zr content. The estimated size $d$ of the observed particles was $(9 \pm 1) \mathrm{nm}$. The diameter of the particles is higher compared to the as-extruded state. No recrystallization was detected. Hence the decrease of the electrical resistivity between $300^{\circ} \mathrm{C}$ and $420^{\circ} \mathrm{C}$ (corresponding to the IIa-stage of the AlScZrPM alloy in Fig. 3) as well as the decrease in microhardness (see Fig. 2) is caused by the coarsening of the $L 1_{2}$-structured particles and by the decrease of their number density. The following resistivity increase at annealing temperatures above $\approx 420^{\circ} \mathrm{C}$ is probably caused by the dissolution of the $\mathrm{Al}_{3}(\mathrm{Sc}, \mathrm{Zr})$ particles.

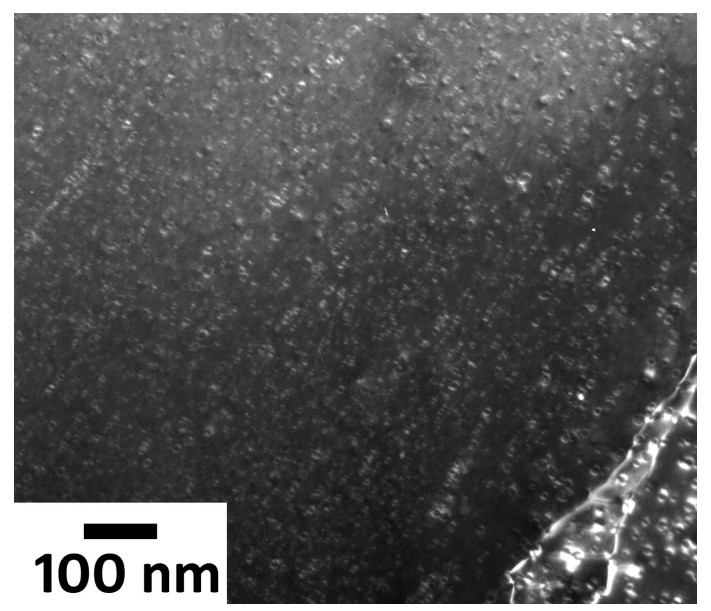

Fig. 4. TEM image of coarsened $L 1_{2}$-structured particles with $\mathrm{Sc}$ and $\mathrm{Zr}$ content in the AlScZrPM alloy annealed up to $420^{\circ} \mathrm{C}$.

The diffusivity $D$ of $\mathrm{Mn}$ atoms is relatively low $\left(D_{400}{ }^{\circ} \mathrm{C}=6.24 \times 10^{-19} \mathrm{~m}^{2} \mathrm{~s}^{-1}[13,21]\right)$ at temperatures below $\approx 400^{\circ} \mathrm{C}$. Therefore, Mn atoms can move only on short distances. However, the calculation and experiments show that Mn-containing dispersoids can form during the heat treatment already at temperatures starting from $\approx 320^{\circ} \mathrm{C}$, e.g. in the deformed Al-Mn-based alloys $[13,14,16,22]$.

Now, we should note that the resistivity annealing curves of the AlMnScZrPM alloy at temperatures above $\approx 330^{\circ} \mathrm{C}$ exhibit a pronounced decrease of the electrical resistivity compared to the AlScZrPM alloy (see Fig. 2). With respect to the solubility limits of Sc and $\mathrm{Zr}$ at comparable temperatures [23-25], it is obvious that the resistivity development in the AlMnScZrPM alloy at annealing temperatures above $\approx 330^{\circ} \mathrm{C}$ (and the existence of the IIb-stage) must be mainly associated with other solute than $\mathrm{Sc}$ and $\mathrm{Zr}$ - mainly $\mathrm{Mn}$. Indeed, the XRD analysis confirms existence of the $\mathrm{Al}_{6} \mathrm{Mn}$ and/or $\mathrm{Al}_{6}(\mathrm{Mn}, \mathrm{Fe})$ particles in the AlMnScZrPM alloy annealed up to $480^{\circ} \mathrm{C}$ (Fig. 5). Although the diffraction peaks are relatively weak due to the small volume fraction. They coincide fairly well with the positions of the $\mathrm{Al}_{6}(\mathrm{Mn}, \mathrm{Fe})$ phase $[16,22]$. Taking into account the pronounced resistivity decrease $(\Delta \rho \approx 15 \mathrm{n} \Omega \mathrm{m})$ and the precipitation of $\mathrm{Al}-\mathrm{Sc}-\mathrm{Zr}$ system $(\Delta \rho \approx 1 \mathrm{n} \Omega \mathrm{m})$, the possible concentration diminution $\Delta c$ of $\mathrm{Mn}$ in the matrix of the AlMnScZrPM alloy after annealing between $300^{\circ} \mathrm{C}$ and 
$495^{\circ} \mathrm{C}$ can be estimated. It was calculated to be equal to $\Delta c_{\mathrm{Mn}}=(0.5 \pm 0.1) \mathrm{wt} \% \mathrm{Mn}$ using the known resistivity contribution of unit Mn-concentration in $\mathrm{Al}$ (e.g. $[25,26])$.

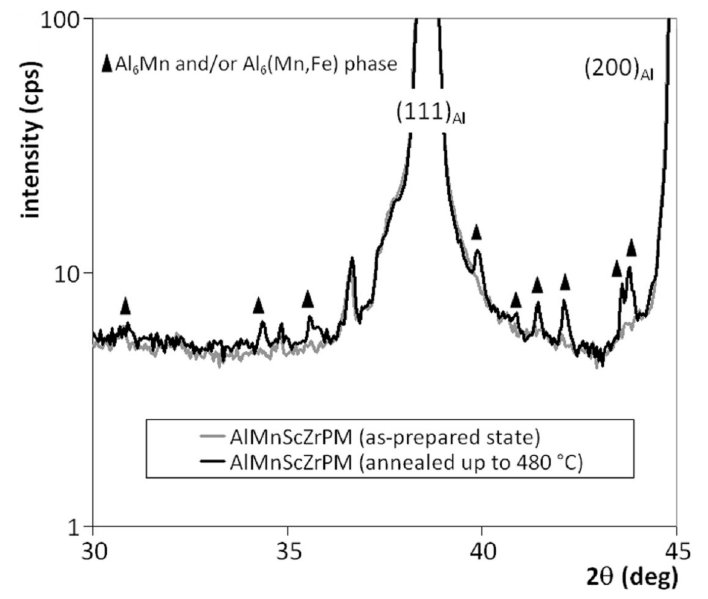

Fig. 5. XRD pattern of the AlMnScZrPM alloy in the as-prepared state and after annealing up to $480^{\circ} \mathrm{C}$.

The experiments in binary as-cast Al-1.5 wt\%Mn alloys [27] as well as in quaternary mould-cast AlMnScZr alloys $[15,16]$ show that Mn-containing particles precipitate during isochronal annealing only at temperatures above $\approx 450{ }^{\circ} \mathrm{C}$. Nevertheless, the present results are consistent with the results on deformed Al-Mn-based and $\mathrm{Al}-\mathrm{Mn}-\mathrm{Sc}-\mathrm{Zr}$ alloys where a fine-grained structure and deformation strain helped to shift the $\mathrm{Al}_{6} \mathrm{Mn}$-phase precipitation towards lower temperatures (e.g. [12, 14, 16, $22,27])$ compared to mould-cast AlMnScZr alloys.

Concerning DSC results, two exothermic effects ( $A$ and $B$ ) were observed in the quaternary AlMnScZrPM alloy. The effect $B$ was not visible at heating rate of $20 \mathrm{~K} / \mathrm{min}$. One exothermic effect $(C)$ was observed in the ternary AlScZrPM alloy only at heating rates 1 and $10 \mathrm{~K} / \mathrm{min}$. The peak temperatures $T_{\mathrm{m}}$ of the effect $A$ and $C$ summarised in Table II can be assigned to the I-stage in resistivity spectrum curves (Fig. 3), that of the effect $\mathrm{B}$ can be assigned to the IIb-stage in Fig. 3. The temperature position $T_{\mathrm{m}}$ of the heat effects shifts to higher temperatures with increasing heating rate.

TABLE II Characteristic temperatures $T_{\mathrm{m}}$ from DSC measurements of the PM alloys.

\begin{tabular}{c|c|c|c|c|c|c}
\hline \hline \multirow{2}{*}{$\begin{array}{c}\text { Notation } \\
\end{array}$} & \multirow{2}{*}{ Effect } & \multicolumn{5}{|c}{$\begin{array}{c}\text { DSC peak temperature } T_{\mathrm{m}}\left[{ }^{\circ} \mathrm{C}\right] \\
\text { for different heating rates }[\mathrm{K} / \mathrm{min}]\end{array}$} \\
\cline { 3 - 7 } & & 1 & 2 & 5 & 10 & 20 \\
\hline AlMnScZrPM alloy & $A$ & 283 & 313 & 331 & 353 & 365 \\
AlMnScZrPM alloy & $B$ & 416 & 445 & 465 & 473 & - \\
AlScZrPM alloy & $C$ & 280 & - & - & 365 & -
\end{tabular}

The Kissinger method [28] gives the following relation between the peak temperature, $T_{\mathrm{m}}$ and the heating rate $\beta$ :

$$
\ln \left(\beta / T_{\mathrm{m}}^{2}\right)=C-Q / R T_{\mathrm{m}},
$$

where $C$ is a constant, $Q$ - the apparent activation energy of the observed process and $R$ - the gas constant (Fig. 6). Results obtained in the AlScZrPM alloy are marked as open symbols in Fig. 6. It can be seen that these values are comparable with those of the AlMnScZrPM alloy regardless of Mn-addition, but the activation energy of the effect $A$ was determined from results obtained in the AlMnScZrPM alloy only.

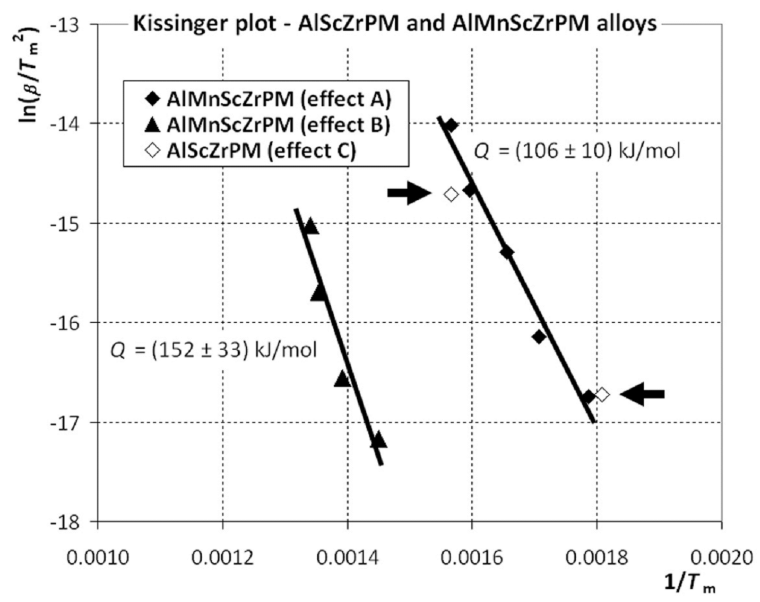

Fig. 6. Kissinger plot for the effects $A$ and $B$ in the AlMnScZrPM alloy from DSC measurements. Results obtained in the AlScZrPM alloy (effect $C$ ) are marked as open symbols and arrows.

The apparent activation energy of the effect $A$ corresponding to the I-stage was calculated as (106 \pm 10) $\mathrm{kJ} \mathrm{mol}^{-1}$. This value is lower than the value for the $\mathrm{Al}_{3} \mathrm{Sc}$ phase precipitation determined by $\mathrm{J}_{\mathrm{O}}$ and $\mathrm{Fu}-$ jikawa [29] in Al-0.15 at.\%Sc alloy $\left(Q=124 \mathrm{~kJ} \mathrm{~mol}^{-1}\right)$. However, it agrees within accuracy with the apparent activation energy $Q$ for precipitation of the $\mathrm{Al}_{3} \mathrm{Sc}$ phase in the cold-rolled A10.2Sc0.1Zr alloys $(Q=$ $\left.(120 \pm 6) \mathrm{kJ} \mathrm{mol}^{-1}\right)[9]$, in $\mathrm{Al}-0.2 \mathrm{wt} \% \mathrm{Sc}$ alloy $(Q=$ $113 \mathrm{~kJ} \mathrm{~mol}^{-1}$ ) [30] and in the cold-rolled AlMnScZr alloy $\left(Q=(106 \pm 13) \mathrm{kJ} \mathrm{mol}^{-1}\right)[16]$.

The apparent activation energy of the effect $B$ was calculated as $Q=(152 \pm 33) \mathrm{kJ} \mathrm{mol}^{-1}$. Scatter is caused by the uncertainty in the determination of $T_{\mathrm{m}}$ in DSC curves but it is comparable to the activation energy $Q=$ $140 \mathrm{~kJ} \mathrm{~mol}{ }^{-1}$ for precipitation of the $\mathrm{Al}_{6} \mathrm{Mn}$ particles in the Al-2.9 wt\%Mn alloy [31] and $Q=149 \mathrm{~kJ} \mathrm{~mol}^{-1}$ for the $\mathrm{Al}_{6}(\mathrm{Mn}, \mathrm{Fe})$ phase precipitation in the 3003 alloy (AlMnFeSiCu-based alloys) [32]. Accordingly, the effect of Mn-addition on the microstructural development can be ascribed to the precipitation of Mn-containing phases.

\section{Conclusions}

The results of the electrical resistometry, microhardness, calorimetric measurements and microstructure investigation in the $\mathrm{Al}-\mathrm{Sc}-\mathrm{Zr}$-based alloys with and with- 
out Mn content prepared by powder metallurgy can be summarized as follows:

1) Dense dispersion of very fine coherent spherical particles of the $\mathrm{Al}_{3} \mathrm{Sc}$ and/or $\mathrm{Al}_{3}(\mathrm{Sc}, \mathrm{Zr})$ phase precipitates during hot extrusion at $350{ }^{\circ} \mathrm{C}$.

2) The decomposition sequence of the supersaturated solid solution of the studied Al-Sc-Zr-based alloys prepared by powder metallurgy is compatible with the recently published decomposition sequence of the $\mathrm{Al}-\mathrm{Sc}-\mathrm{Zr}$ system and the formation of $\mathrm{Mn}, \mathrm{Fe}$-containing particles (in case of the Al-Mn-Sc-Zr alloy).

3) The apparent activation energy for precipitation of the $\mathrm{Al}_{3} \mathrm{Sc}$ particles in the AlMnScZrPM alloy was determined as $(106 \pm 10) \mathrm{kJ} \mathrm{mol}^{-1}$.

4) The precipitation of the $\mathrm{Al}_{6} \mathrm{Mn}$ and/or $\mathrm{Al}_{6}(\mathrm{Mn}, \mathrm{Fe})$ phase in the AlMnScZrPM alloy has a negligible effect on hardness.

5) The apparent activation energy for precipitation of the $\mathrm{Al}_{6} \mathrm{Mn}$ particles in the AlMnScZrPM alloy was determined as $(152 \pm 33) \mathrm{kJ} \mathrm{mol}^{-1}$.

\section{Acknowledgments}

This work was supported by The Czech Science Foundation (GACR), project No. GP P107/11/P201.

\section{References}

[1] L.S. Toropova, D.G. Eskin, M.L. Kharakterova, T.V. Dobatkina, Advanced Aluminium Alloys Containing Scandium - Structure and Properties, Gordon and Breach, The Netherlands 1998.

[2] V. Ocenasek, M. Slamova, Mater. Charact. 47, 157 (2001), DOI: 10.1016/S1044-5803(01)00165-6.

[3] B. Smola, I. Stulíková, V. Očenášek, J. Pelcová, V. Neubert, Mater. Sci. Eng. A 462, 370 (2007), DOI: $10.1016 /$ j.msea. 2005.11.075.

[4] J. Røyset, R. Ryum, Int. Mater. Rev. 50, 19 (2005), DOI: $10.1179 / 174328005 X 14311$.

[5] K.E. Knipling, R.A. Karnesky, C.P. Lee, D.C. Dunand, D.N. Seidman, Acta Mater. 58, 5184 (2010), DOI: 10.1016/j.actamat.2010.05.054.

[6] B. Forbord, H. Hallem, J. Røyset, K. Marthinsen, Mater. Sci. Eng. A 475, 241 (2008), DOI: $10.1016 /$ j.msea.2007.04.054.

[7] M. Kolář, V. Očenášek, J. Uhliřr, I. Stulíková, B. Smola, M. Vlach, V. Neubert, K. Sperlink, Mater. Sci. Forum 567-568, 357 (2008), DOI: 10.4028/ www.scientific.net/MSF.567-568.357.

[8] M. Vlach, B. Smola, I. Stulíková, V. Očenášek, Int. J. Mater. Res. 100, 420 (2009), DOI: 10.3139/ 146.110022 .

[9] M. Vlach, I. Stulíková, B. Smola, N. Žaludová, J. Cerná, J. Alloys Comp. 492, 143 (2010), DOI: 10.1016/j.jallcom.2009.11.126.

[10] W. Lefebvre, F. Danoix, H. Hallem, B. Forbord, A. Bostel, K. Marthinsen, J. Alloys Comp. 470, (2009), DOI: 10.1016/j.jallcom.2008.02.043.
[11] X. Xia, Scr. Met. 28, 1213 (1993), DOI: $10.1016 /$ 0956-716X(93)90456-3.

[12] Y. Birol, Scr. Mater. 60, 5 (2009), DOI: 10.1016/ j.scriptamat.2008.07.047.

[13] B. Forbord, L. Auran, W. Lefebvre, H. Hallem, K. Marthinsen, Mater. Sci. Eng A 424, 174 (2006), DOI: $10.1016 /$ j.msea.2006.03.044.

[14] M. Cieslar, M. Slámová, J. Uhlír, C. Coupeau, J. Bonneville, Kovove Mater. 45, 91 (2007).

[15] M. Vlach, I. Stulíková, B. Smola, N. Žaludová, Mater. Charact. 61, 1400 (2010), DOI: 10.1016/j.matchar. 2010.10.006.

[16] M. Vlach, I. Stulíková, B. Smola, H. Císařová, J. Piešová, S. Daniš, R. Gemma, J. Málek, D. Tanprayoon, V. Neubert, Int. J. Mater. Res. 103, 814 (2012), DOI: 10.3139/146.110712.

[17] R. Ünal, K.U. Kainer, Powder Metall. 41, 119 (1998).

[18] V. Neubert, B. Smola, I. Stulíková, A. Bakkar, J. Reuter, Mater. Sci. Eng. A 464, 358 (2007), DOI: 10.1016/j.msea.2007.03.070.

[19] H. Fujii, M. Sugamata, J. Kaneko, M. Kubota, Mater Sci. Forum 396-402, 245 (2002), DOI: 10.4028/ www.scientific.net/MSF.396-402.245.

[20] C.B. Fuller, J.L. Murray, D.N. Seidman, Acta Mater. 53, 5401 (2005), DOI: 10.1016/j.actamat.2005.08.016.

[21] K.E. Knipling, D.C. Dunand, D.N. Seidman, Int. J. Mater. Res. 97, 246 (2006).

[22] Y. Birol, J. Alloys Comp. 471, 122 (2009), DOI: 10.1016/j.jallcom.2008.04.005.

[23] Y. Kang, A.D. Pelton, P. Chartrand, C.D. Fuerst, Calphad 32, 413 (2008), DOI: 10.1016/j.calphad. 2008.03.002.

[24] G.M. Novotny, A.J. Ardell, Mater. Sci. Eng A $\mathbf{3 1 8}$ 144 (2001), DOI: 10.1016/S0921-5093(01)01326-0.

[25] S.I. Fujikawa, M. Sugaya, H. Takei, K.I. Hirano, J. Less-Common Met. 63, 87 (1979), DOI: 10.1016/ 0022-5088(79)90211-X.

[26] P. Olafsson, R. Sandstrom, A.J. Karlsson, J. Mater. Sci. 32, 4383 (1997), DOI: 10.1023/ A:1018680024876.

[27] V. Očenášek, P. Homola, M. Kolář, J. Uhlír, M. Cieslar, in: Metal 2009, 18th Int. Conf. Metallurgy and Materials, Hradec nad Moravici, Tanger, Ostrava 2009, p. 413.

[28] M.J. Starink, Thermochim. Acta 404, 163 (2003), DOI: 10.1016/S0040-6031(03)00144-8.

[29] H. Jo, S.I. Fujikawa, Mater. Sci. Eng. A 171, 151 (1993), DOI: 10.1016/0921-5093(93)90401-Y.

[30] K. Fan, F. Liu, K. Zhang, G.C. Yang, Y.H. Zhou, J. Cryst. Growth 311, 4660 (2009), DOI: 10.1016/ j.jcrysgro.2009.09.003.

[31] M.M. Karnowsky, M. Moss, C. Stein, Scr. Metall. 8, 513 (1974), DOI: 10.1016/0036-9748(74)90061-1.

[32] N.J. Luiggi, Metall. Mater. Trans. A 28, 149 (1997), DOI: $10.1007 / \mathrm{s} 11663-997-0137-9$. 